\title{
Effect of Ferritin on $\lambda$ DNA Strand Breaks in the Reaction System of Alloxan Plus NADPH-Cytochrome P450 Reductase: Ferritin's Role in Diabetogenic Action of Alloxan
}

\author{
Koichi SAKURAI* and Taketo OgISO \\ Hokkaido Institute of Pharmaceutical Sciences, 7-1, Katsuraoka-cho, Otaru 047-02, Japan. \\ Received July 26, 1994; accepted October 13, 1994
}

\begin{abstract}
The incubation of $\lambda D N A$ in the reaction system of alloxan plus NADPH-cytochrome P450 reductase (fp2) in the presence of ferritin caused strand breaks after a lag time of about $5 \mathrm{~min}$. Addition of ferritin to the reaction system at concentrations below $50 \mu \mathrm{g} / \mathrm{ml}$ caused the strand breaks of DNA in a concentration-dependent fashion. Catalase, scavengers of hydroxyl radicals (HO·) and iron-chelators almost completely inhibited the DNA strand breaks, but superoxide dismutase (SOD) did not, suggesting that the strand breaks are induced by the generation of $\mathrm{HO} \cdot$ via the reaction of $\mathrm{H}_{2} \mathrm{O}_{2}$ and $\mathrm{Fe}$ (II), namely, the Fenton reaction. When the ferritin was incubated in the reaction system of alloxan plus fp2, the iron release from ferritin increased with incubation time depending on the amount of $\mathrm{fp} 2$. The addition of increasing concentrations of ferritin to the reaction system resulted in progressive increase in the iron release and a decrease in the electron spin resonance signal intensity of alloxan radical (HA·), the one electron reduced form of alloxan, suggesting that HA $\cdot$ generated in the reaction system is capable of releasing iron from ferritin. These results support the possibility that the iron released from ferritin may be involved in the diabetogenic action of alloxan.
\end{abstract}

Key words ferritin; alloxan; DNA strand break; NADPH-cytochrome P450 reductase; hydroxyl radical; alloxan radical

Alloxan is widely used in studies of experimental diabetes because this agent destroys pancreatic $\beta$-cells with a specific selectivity. ${ }^{1,2)}$ Since this diabetogenic action is inhibited by superoxide dismutase (SOD), catalase or hydroxyl radical $(\mathrm{HO} \cdot)$ scavengers such as thiourea, dimethylsulfoxide (DMSO) and $N, N$-dimethyl urea ${ }^{3-5}$ ) the action of alloxan is believed to involve oxygen radicals. In the reaction system of alloxan with reduced glutathione (GSH) in the presence of Fe(III)-ethylenediaminetetraacetic acid (EDTA), we have proposed ${ }^{6}$ that alloxan causes the rise of superoxide radical $\left(\mathrm{O}_{2}^{-}\right)$and hydrogen peroxide $\left(\mathrm{H}_{2} \mathrm{O}_{2}\right)$ during the redox cycling between alloxan and alloxan radical (HA.) (reaction $1-3$ ) and that $\mathrm{HO}^{-}$is generated by HA $\cdot$ through a Fenton reaction (reaction 4 and 5).

$$
\begin{aligned}
& \text { alloxan }+\mathrm{GSH} \rightarrow \mathrm{HA} \cdot+1 / 2 \mathrm{GSSG} \\
& \mathrm{HA} \cdot+\mathrm{O}_{2} \rightarrow \text { alloxan }+\mathrm{O}_{2}^{-} \\
& \mathrm{O}_{2}^{-}+\mathrm{O}_{2}^{-}+2 \mathrm{H}^{+} \rightarrow \mathrm{H}_{2} \mathrm{O}_{2}+\mathrm{O}_{2} \\
& \mathrm{HA} \cdot+\mathrm{Fe}(\mathrm{III}) \rightarrow \text { alloxan }+\mathrm{Fe}(\mathrm{II}) \\
& \mathrm{H}_{2} \mathrm{O}_{2}+\mathrm{Fe}(\mathrm{II}) \rightarrow \mathrm{HO} \cdot+\mathrm{HO}^{-}+\mathrm{Fe}(\mathrm{III})
\end{aligned}
$$

Several researchers have shown, ${ }^{7,8)}$ with experimental systems using isolated pancreatic islets of rats, that the primary step of alloxan toxicity is the generation of $\mathrm{HO}$. by which the DNA of pancreatic islets is attacked to produce strand breaks. These findings suggest that $\mathrm{HO}$ which was generated by HA - through a Fenton-type reaction initiates the DNA strand breaks in pancreatic islet cells.

The involvement of iron in the diabetogenic action of -alloxan has also been indicated by several lines of studies, in vivo ${ }^{9,10)}$ and in vitro. ${ }^{11)}$ In a biological system, the production of $\mathrm{HO} \cdot$ was catalyzed by transition metals such as iron. ${ }^{12)}$ However, there was no direct evidence for the existence of free iron capable of inducing this toxicity under normal physiological conditions, because the metabo-

* To whom correspondence should be addressed. lism of iron is tightly controlled and regulated by the iron-binding proteins, transferrin and ferritin. ${ }^{13)}$ Most intercellular iron except for heme iron is stored within ferritin from which various reducing agents such as $\mathrm{O}_{2}^{-}$, ascorbate and GSH can liberate it. ${ }^{14-16)}$ The iron released from ferritin can produce $\mathrm{HO} \cdot$ from $\mathrm{H}_{2} \mathrm{O}_{2}$ through the Fenton reaction (reaction 5). ${ }^{17,18)}$

We established ${ }^{19)}$ that the generation of $\mathrm{HA} \cdot$ was catalyzed by NADPH-cytochrome $\mathrm{P} 450$ reductase [E.C.1.6.2.4] (fp2) purified from rat liver microsomes. To clarify the mechanism of DNA strand breaks by alloxan in islet cells, we examined the effect of ferritin on $\lambda \mathrm{DNA}$ strand breaks in the HA-generating system of alloxan plus fp2.

\section{MATERIALS AND METHODS}

Materials Alloxan, $\mathrm{FeSO}_{4}$ (Fe(II)), DMSO and ferritin (from horse spleen) were purchased from Wako Pure Chemical Industries, Ltd., Japan. A solution of Fe(II) was made up freshly just before use in dilute $\mathrm{HCl}$ purged with $\mathrm{N}_{2}$ gas for $5 \mathrm{~min}$. SOD (from bovine erythrocytes), catalase (from bovine liver, thymol-free) and apotransferrin (from human) were obtained from Sigma Co., U.S.A. The apotransferrin was dissolved in $10 \mathrm{~mm}$ sodium phosphate buffer, $\mathrm{pH} 7.4$, containing $5 \mathrm{~mm} \mathrm{NaHCO} 3 . \lambda \mathrm{DNA}$ (M.W. $31.5 \times 10^{6}$ daltons, 48502 base pairs) was from Nippon Gene, Ltd., Japan; phenobarbital (PB) from Sankyo Ltd., Japan, bathophenanthroline disulfonate from Dojindo Laboratories Co. Ltd., Japan; dimethylthiourea (DMTU) from Aldrich Chemical Co., Inc., U.S.A. and desferrioxamine from CIBA Geigy, Switzerland. Other reagents used in the experiments were of the highest grade.

Detection of DNA Strand Breaks To remove the Tris- $\mathrm{HCl}$ buffer and EDTA, the commercial 2 DNA solution was dialyzed against sterilized $10 \mathrm{~mm}$ sodium

(C) 1995 Pharmaceutical Society of Japan 
phosphate buffer, $\mathrm{pH} 7.4$, containing $0.15 \mathrm{M} \mathrm{NaCl}$ at $4{ }^{\circ} \mathrm{C}$ for $2 \mathrm{~d}$ with three changes of the same buffer. After the incubation of DNA $(20 \mu \mathrm{g} / \mathrm{ml})$ in $10 \mathrm{~mm}$ sodium phosphate buffer, $\mathrm{pH} 7.4$, containing $1 \mathrm{~mm}$ alloxan, $0.5 \mathrm{~mm}$ NADPH, $50 \mu \mathrm{g} / \mathrm{ml}$ ferritin, $0.15 \mathrm{unit} / \mathrm{ml} \mathrm{fp} 2$ and $0.15 \mathrm{M} \mathrm{NaCl}$ at $37^{\circ} \mathrm{C}$ for various periods of time, the DNA strand breaks were observed as described previously by using the electrophoresis method, ${ }^{20)}$ and were photographed in ultraviolet light.

Purification of $\mathbf{f p 2}$ Male Wistar strain rats weighing about $250 \mathrm{~g}$ ( 7 to 8 weeks old) were used in this experiment. $\mathrm{PB}$ was injected intraperitoneally to rats at the dose of $80 \mathrm{mg} / \mathrm{kg}$ body weight daily for $4 \mathrm{~d}$. Liver microsomes were prepared by ultracentrifugation as described by Ernster $e t$ $\mathrm{al}^{21)}$ and washed once with $0.15 \mathrm{M} \mathrm{KCl}$. The fp2 was prepared from this microsomal preparation according to the method of Yasukochi and Masters, ${ }^{22)}$ with a minor modification. Emulgen 911 (Kao Tokyo, Japan) at 30\% concentration was used as a substitute for Renex 690 . The fp2 solution obtained here contained $25 \%$ glycerol which has been proposed to react with $\mathrm{HO} \cdot$. To remove the glycerol, the $\mathrm{fp} 2$ solution was diluted with cold sterilized $10 \mathrm{~mm}$ sodium phosphate buffer, $\mathrm{pH} 7.4$, containing $0.15 \mathrm{M}$ $\mathrm{NaCl}$, and then concentrated with ultrafiltration (an Amicon Centricon-30). This process was repeated three times. The concentration of glycerol in the fp 2 solution obtained here was not more than $3 \mu \mathrm{m}$. The homogeneity of fp2 obtained was established by sodium dodecyl sulfate polyacrylamide gel electrophoresis. The activity of $\mathrm{fp} 2$ was measured at $25^{\circ} \mathrm{C}$ by monitoring the rate of reduction of cytochrome $\mathrm{c}$ at $550 \mathrm{~nm}$ (using an extinction coefficient of $\left.21.1 \mathrm{~mm}^{-1} \cdot \mathrm{cm}^{-1}\right)$. One unit of activity was defined as $1 \mu \mathrm{mol}$ of cytochrome $\mathrm{c}$ reduced per $\mathrm{min} / \mathrm{ml}$. The activity of fp 2 used in this experiment was $67 \mathrm{unit} / \mathrm{mg}$ of protein.

Preparation of Ferritin and Iron Release Commercial ferritin was incubated in $10 \mathrm{~mm}$ sodium phosphate buffer, $\mathrm{pH} 7.4$, containing $10 \mathrm{~mm}$ EDTA at $4{ }^{\circ} \mathrm{C}$ and the solution was applied to a Sepharose 6B (Pharmacia Fine Chemicals, Sweden) column $(2.6 \times 80 \mathrm{~cm})$ previously equilibrated with $10 \mathrm{~mm}$ sodium phosphate buffer, $\mathrm{pH}$ 7.4. Ferritin fractions were collected and concentrated by ultrafiltration. The iron content of ferritin was determined to be $0.22 \mathrm{mg} \mathrm{Fe}$ (III) $/ \mathrm{mg}$ of ferritin with a polarized Zeeman atomic absorption spectrophotometer (Hitachi 180-80). The iron release from ferritin was determined in the reaction system of alloxan plus fp 2 at $37^{\circ} \mathrm{C}$ spectrophotometrically using the ferrous iron chelator bathophenanthroline sulfonate, the increase in absorbance at $530 \mathrm{~nm}\left(\varepsilon=22.14 \mathrm{~mm}^{-1}\right)$ was monitored with a Hitachi model U-2000 spectrophotometer. ${ }^{15)}$

Detection of Alloxan Radical The generation of HA in the reaction system of alloxan plus fp 2 was detected as described previously by using an ESR (JEOL model JES-RE1X) at room temperature. ${ }^{6)}$ The relative intensity of HA - was determined by measuring the peak height at the center hyperfine line of the ESR spectrum.

\section{RESULTS}

Effect of Ferritin on DNA Strand Breaks in the Reaction System of Alloxan Plus fp2 As shown in Fig. 1, when the DNA was incubated in the reaction system of alloxan plus fp2 in the absence of ferritin, the strand breaks were not

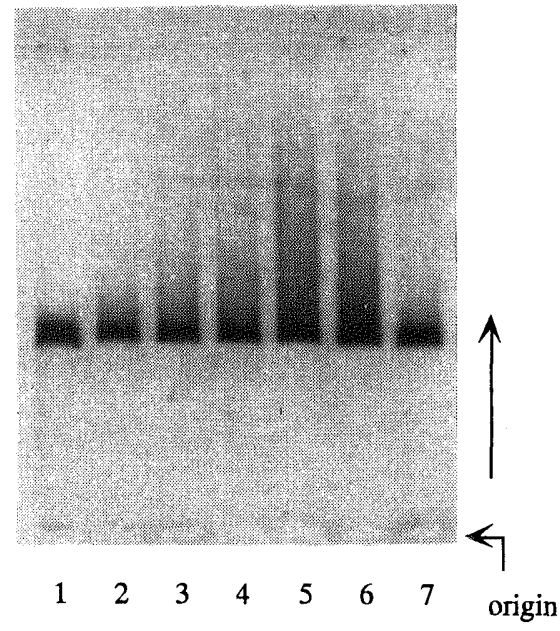

Fig. 1. Effect of Ferritin-Concentrations on DNA Strand Breaks in the Reaction System of Alloxan Plus $\mathrm{fp} 2$

The reaction mixture consisted of $1 \mathrm{~mm}$ alloxan, $0.5 \mathrm{~mm} \mathrm{NADPH}, 0.15 \mathrm{unit} / \mathrm{ml}$ fp2, $0.15 \mathrm{M} \mathrm{NaCl}, 20 \mu \mathrm{g} / \mathrm{ml}$ lDNA and various concentrations of ferritin in $10 \mathrm{mM}$ sodium phosphate buffer, $\mathrm{pH} 7.4$. After the incubation for $20 \mathrm{~min}$ at $37^{\circ} \mathrm{C}$, the DNA strand breaks were detected by the method described in Materials and Methods. The concentrations of ferritin were: track $1,0 \mu \mathrm{g} / \mathrm{ml} ; 2,10 \mu \mathrm{g} / \mathrm{ml} ; 3$, $20 \mu \mathrm{g} / \mathrm{ml} ; 4,30 \mu \mathrm{g} / \mathrm{ml} ; 5,50 \mu \mathrm{g} / \mathrm{ml} ; 6,70 \mu \mathrm{g} / \mathrm{ml}$ and $7,100 \mu \mathrm{g} / \mathrm{ml}$.

observed (track 1). The addition of ferritin to the reaction system at concentrations below $50 \mu \mathrm{g} / \mathrm{ml}$ (as $\mathrm{Fe}$ (III) $0.19 \mathrm{~mm}$ ) caused DNA strand breaks in a concentrationdependent fashion (tracks 2-5). The addition of ferritin to the reaction system above $70 \mu \mathrm{g} / \mathrm{ml}$ resulted in a decrease in the extent of the DNA strand breaks (tracks 6 and 7). Although data are not shown, the strand breaks were not observed without either alloxan, NADPH or $\mathrm{fp} 2$ in the reaction system in the presence of ferritin. These results indicate that ferritin is required for the DNA strand breaks in the reaction system of alloxan plus $\mathrm{fp} 2$.

As shown in Fig. 2, the incubation of DNA in the reaction system in the presence of $50 \mu \mathrm{g} / \mathrm{ml}$ ferritin caused DNA strand breaks after a lag time of about 5 min (A). When the DNA was incubated in the reaction system in the presence of $10 \mu \mathrm{M} \mathrm{Fe}$ (II), the strand breaks of DNA increased with incubation time (B). These results indicate the requirement for longer incubation time in the presence of ferritin than $\mathrm{Fe}(\mathrm{II})$ to induce the strand breaks, and suggest that the iron released from ferritin catalyzes these strand breaks.

Release of Iron from Ferritin As shown in Fig. 3, when ferritin was incubated in the reaction system of alloxan plus $\mathrm{fp} 2$, the amount of released iron from ferritin increased with incubation time in the range from 0.03 to $0.15 \mathrm{unit} / \mathrm{ml}$ depending on $\mathrm{fp} 2$ amount. When the $\mathrm{fp} 2$ was omitted from the reaction system, little release of iron was observed.

As shown in Table I, the rate of iron release from ferritin was $8.8 \mu \mathrm{M} / 20 \mathrm{~min}$ under the experimental conditions used here. When alloxan or NADPH was omitted from the reaction system, very little iron release was seen. The addition of SOD to the reaction system had no significant effect on the rate of the iron release while catalase brought about a slight increase. These results indicate that $\mathrm{O}_{2}^{-}$is not directly involved in the release in the reaction system of alloxan plus $\mathrm{fp} 2$, and suggest that $\mathrm{H}_{2} \mathrm{O}_{2}$ generated in the reaction system reoxidizes $\mathrm{Fe}$ (II) to $\mathrm{Fe}$ (III). 

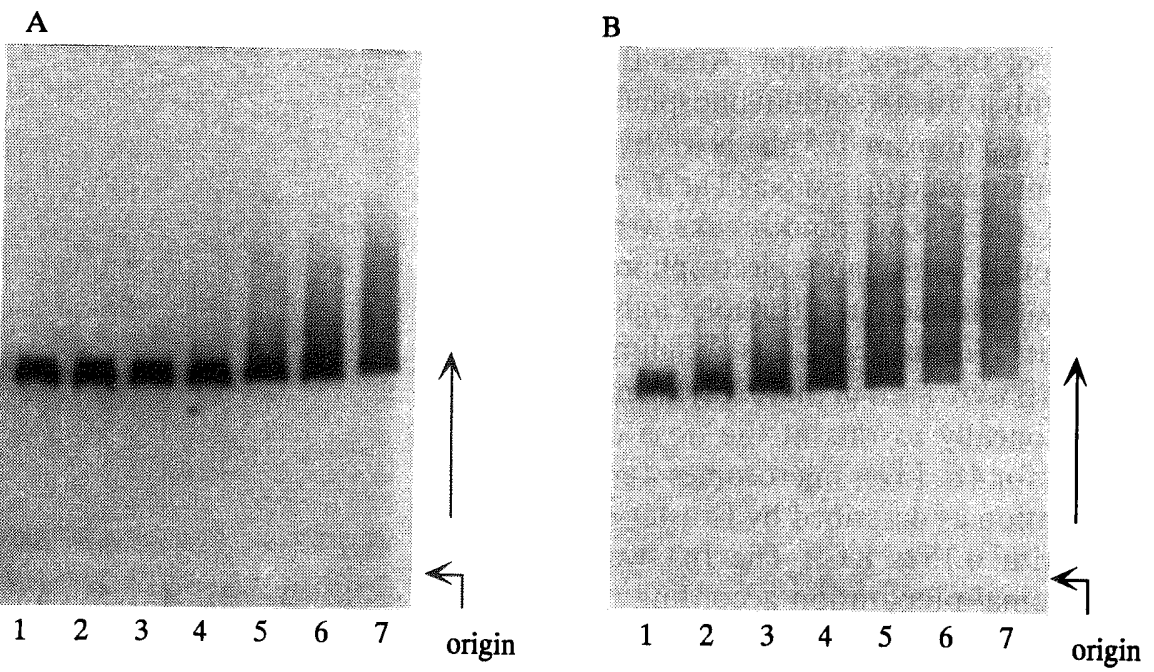

Fig. 2. Time Course of DNA Strand Breaks in the Reaction System of Alloxan Plus fp2 in the Presence of Ferritin or Fe(II)

The reaction mixture consisted of $1 \mathrm{~mm}$ alloxan, $0.5 \mathrm{~mm} \mathrm{NADPH}, 0.15 \mathrm{unit} / \mathrm{ml} \mathrm{fp} 2$ and $0.15 \mathrm{M} \mathrm{NaCl}$ in $10 \mathrm{~mm}$ sodium phosphate buffer, $\mathrm{pH} 7.4 . \lambda \mathrm{DNA}(20 \mu \mathrm{g} / \mathrm{ml}) \mathrm{was}$ incubated at $37^{\circ} \mathrm{C}$ in the reaction mixture in the presence of $50 \mu \mathrm{g} / \mathrm{ml}$ ferritin (A) or $10 \mu \mathrm{M} \mathrm{Fe}$ (II) (B). The incubation times were: track 1, $0 \mathrm{~min} ; 2,1 \mathrm{~min} ; 3,3 \mathrm{~min} ; 4$, $5 \mathrm{~min} ; 5,10 \mathrm{~min} ; 6,20 \mathrm{~min}$ and $7,30 \mathrm{~min}$.

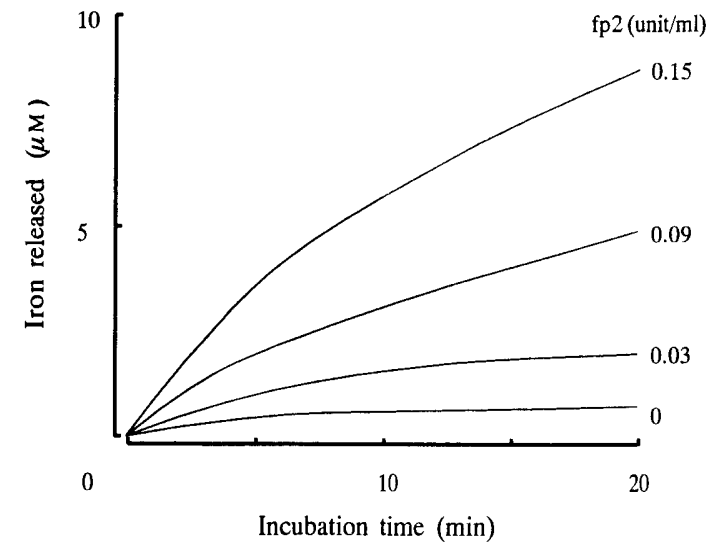

Fig. 3. Time Course of Release of Iron from Ferritin in the Reaction System of Alloxan Plus fp2

The reaction mixtures consisted of $1 \mathrm{~mm}$ alloxan, $0.5 \mathrm{mM} \mathrm{NADPH}, 0.5 \mathrm{mg} / \mathrm{ml}$ ferritin, $1 \mathrm{~mm}$ bathophenanthroline sulfonate and various concentrations of $\mathrm{fp} 2$ in

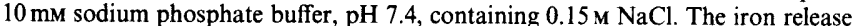
was determined as described in Materials and Methods. The amounts of $\mathrm{fp} 2$ are indicated on the graph.

TABLE I. Iron Release from Ferritin in the Reaction System of Alloxan Plus fp2

\begin{tabular}{ccc}
\hline \hline Condition & $\begin{array}{c}\text { Iron release } \\
(\mu \mathrm{M} / 20 \mathrm{~min})\end{array}$ & $\begin{array}{c}\text { Percent of control } \\
(\%)\end{array}$ \\
\hline Reaction system & $8.8 \pm 0.4$ & 100 \\
- Alloxan & $1.5 \pm 0.1$ & 17 \\
- NADPH & $0.1 \pm 0.0$ & 1 \\
$+100 \mathrm{U} / \mathrm{ml}$ SOD & $7.7 \pm 0.4$ & 88 \\
$+140 \mathrm{U} / \mathrm{ml}$ catalase & $10.1 \pm 0.3$ & 116 \\
\hline
\end{tabular}

The reaction system consisted of $1 \mathrm{~mm}$ alloxan, $0.5 \mathrm{~mm} \mathrm{NADPH}, 0.15 \mathrm{unit} / \mathrm{ml}$ $\mathrm{fp} 2,50 \mu \mathrm{g} / \mathrm{ml}$ ferritin, $1 \mathrm{~mm}$ bathophenanthroline sulfonate and $0.15 \mathrm{M} \mathrm{NaCl}$ in $10 \mathrm{~mm}$ sodium phosphate buffer, $\mathrm{pH}$ 7.4. The iron release was determined as described in the Materials and Methods. Each value represents the mean \pm S.E. of triplicate experiments.

As previously reported, ${ }^{23,24)}$ in the reaction system of alloxan with GSH, the iron release from ferritin occurred through a direct reduction of ferritin iron by $\mathrm{HA} \cdot$, the one electron reduced form of alloxan. Therefore, we

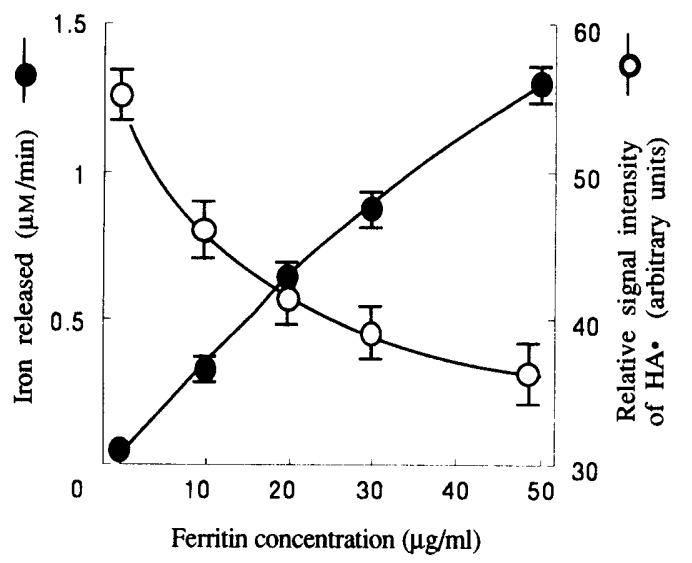

Fig. 4. Effect of Ferritin on Iron Release and Generation of HA.

The release of iron from ferritin was carried out in the reaction mixtures consisting of $1 \mathrm{~mm}$ alloxan, $0.5 \mathrm{~mm}$ NADPH, $0.15 \mathrm{unit} / \mathrm{ml} \mathrm{fp} 2,1 \mathrm{~mm}$ bathophenanthroline sulfonate and various concentrations of ferritin in $10 \mathrm{~mm}$ sodium phosphate buffer, $\mathrm{pH} 7.4$, containing $0.15 \mathrm{M} \mathrm{NaCl}$. The determination of signal intensity of $\mathrm{HA}$ - was performed in the reaction mixtures without bathophenanthroline sulfonate. Other conditions were as described in Materials and Methods. Each point represents the mean \pm S.E. of triplicate experiments.

investigated the possible participation of $\mathrm{HA} \cdot$ in the iron release from ferritin in the reaction system of alloxan plus fp2. As shown in Fig. 4, the addition of increasing concentrations of ferritin to the reaction system resulted in progressive increase in the iron release with decreasing of the ESR signal intensity. The ESR spectrum obtained here agreed with that of the $\mathrm{HA} \cdot$ reported in the previous paper $\left.\left(a^{\mathrm{N}}=a^{\mathrm{H}}=0.45 \mathrm{G}, g=2.005\right){ }^{6}{ }^{6}\right)$ These results suggest that $\mathrm{HA} \cdot$ generated in the reaction system of alloxan plus fp2 is capable of releasing iron from ferritin.

Effect of Oxygen Radical Scavengers and Iron-Chelators on DNA Strand Breaks We next investigated the effect of SQD, catalase, $\mathrm{HO} \cdot$ scavengers and iron-chelators on the DNA strand breaks in the reaction system of alloxan plus fp2 in the presence of ferritin. As shown in Fig. 5, calatase (track 3) and HO- scavengers (tracks 4 and 5) almost completely inhibited the DNA strand breaks, but SOD had little effect (track 2), indicating the possible participation of $\mathrm{H}_{2} \mathrm{O}_{2}$ and $\mathrm{HO} \cdot$ in these breaks. 


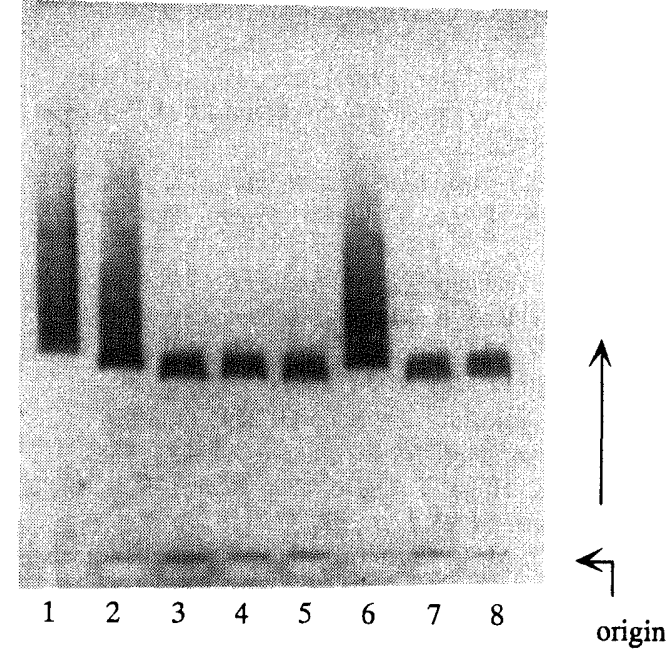

Fig. 5. Effect of SOD, Catalase, HO- Scavengers and Iron-Chelators on DNA Strand Breaks

The experimental conditions were the same as given in Fig. 2, except that the incubation time was $20 \mathrm{~min}$. Track 1, control; $2,+110 \mathrm{U} / \mathrm{ml} \mathrm{SOD} ; 3,+140 \mathrm{U} / \mathrm{ml}$ catalase; 4, +10 mM DMTU; 5, +10 mM DMSO; 6, +4 mg/ml apotransferrin; 7, $+0.2 \mathrm{~mm}$ desferrioxamine and $8,+0.2 \mathrm{~mm}$ bathophenanthroline sulfonate.

An addition of apotransferrin $(4 \mathrm{mg} / \mathrm{ml})$, a $\mathrm{Fe}(\mathrm{III})$ binding protein which has $100 \mu \mathrm{M} \mathrm{Fe}(\mathrm{III})$-binding capacity, to the reaction system did not inhibit the DNA strand breaks (track 6). However, desferrioxamine, a Fe(III)chelator, and bathophenanthroline, a $\mathrm{Fe}(\mathrm{II})$-chelator, strikingly inhibited then (tracks 7 and 8). Although the data are not shown, when ferritin was replaced by Fe(II) or $\mathrm{Fe}(\mathrm{III})$ in the reaction system, almost the same results were obtained. These findings suggest that both $\mathrm{Fe}$ (II) and $\mathrm{Fe}(\mathrm{III})$ are involved in DNA strand breaks under the experimental conditions presented here.

\section{DISCUSSION}

Alloxan induces DNA strand breaks in rat pancreatic islet cells in vivo and in vitro. ${ }^{7.25)}$ The strand breaks seem to be important in the development of diabetes mellitus. Previous studies in this laboratory have demonstrated that $\lambda$ DNA strand breaks result in the HA -generating system of alloxan with GSH in the presence of $\mathrm{Fe}(\mathrm{III}),{ }^{26)}$ and that the generation of $\mathrm{HA} \cdot$ is catalyzed by $\mathrm{fp} 2$ in the islet cell. ${ }^{19)}$ In the present study, we showed that the strand breaks of $\lambda$ DNA were caused by the reaction system of alloxan plus fp2 in the presence of ferritin (Fig. 1) and were strongly inhibited by catalase, $\mathrm{HO} \cdot$ scavengers and iron-chelators, but not effectively by SOD (Fig. 5). These results indicate that $\mathrm{H}_{2} \mathrm{O}_{2}$ and $\mathrm{HO} \cdot$ together with $\mathrm{Fe}$ are involved in the strand breaks. Although the participation of ferritin itself in the reaction of $\mathrm{HO}$-generating is uncleared, ${ }^{17,27)}$ several studies have confirmed that the iron released from ferritin can catalyze the generation of $\mathrm{HO} \cdot$ in the reaction system of xanthine with xanthine oxidase. ${ }^{17,18)}$ The present study showed that the release of iron from ferritin was caused by the HA $\cdot$ generated in the reaction system of alloxan plus fp2 (Fig. 4). From these results, we concluded that the strand breaks of DNA in the presence of ferritin were directly induced by the generation of $\mathrm{HO} \cdot$ via the $\mathrm{HA} \cdot$-dependent Fenton reac- tion.

Incubation of DNA in the reaction system in the presence of ferritin resulted in the strand breaks after a lag time of about $5 \mathrm{~min}$ (Fig. 2). Under the same experimental conditions, with $5 \mathrm{~min}$ incubation, the amount of released iron was about $3 \mu \mathrm{M}$ (Fig. 3). The strand breaks were also observed by the addition more than $3 \mu \mathrm{M}$ of $\mathrm{Fe}(\mathrm{II})$ to the reaction system (data not shown). These results suggest that the lag time can be attributed to the length of time required to release the iron from ferritin and that the release of iron is a rate-limiting step in the strand breaks of DNA in the reaction system.

Since the DNA strand breaks were inhibited by either $\mathrm{Fe}(\mathrm{II})$ - or $\mathrm{Fe}(\mathrm{III})$-chelators in the reaction system of alloxan plus $\mathrm{fp} 2$ in the presence of ferritin (Fig. 5), the redox-cycling of released iron appears to occur during the reaction of strand breaks. Although apotransferrin has been reported to inhibit the reaction of iron-dependent $\mathrm{HO} \cdot$ generation in the reaction system of xanthine with xanthine oxidase, ${ }^{28)}$ it does not inhibit the DNA strand breaks in the reaction system of alloxan plus fp2 in the presence of ferritin (Fig. 5). In our previous studies, ${ }^{26)}$ we showed that the apotransferrin did not remove iron from the DNA-Fe(III) complex which was reduced by HA - to DNA-Fe(II) complex, suggesting that the Fe bound to DNA catalyzes the site-specific generation of $\mathrm{HO} \cdot$ via the Fenton-type reaction (reaction 6).

$$
\mathrm{DNA}-\mathrm{Fe}(\mathrm{II})+\mathrm{H}_{2} \mathrm{O}_{2} \rightarrow \mathrm{DNA}-\mathrm{Fe}(\mathrm{III})+\mathrm{HO}^{+}{ }^{+} \mathrm{HO}^{-}
$$

These findings indicate that the iron (Fe(II) or $\mathrm{Fe}(\mathrm{III})$ ) bound to DNA involved in the DNA strand breaks which are caused by the site-specific generation of $\mathrm{HO} \cdot$ through the Fenton reaction in the reaction system of alloxan plus fp2 in the presence of ferritin.

One possible reason why the adding of an excess (more than $70 \mu \mathrm{g} / \mathrm{ml}$ ) of ferritin inhibited the strand breaks of DNA in the reaction system (Fig. 1) is as follows: the HA. which has been reported to reduce $\mathrm{O}_{2}$ by one electron to $\mathrm{O}_{2}^{-6,29)}$ may be predominantly consumed by the releasing reaction of iron by an interaction with excess ferritin. In fact, the ESR signal of HA - could not be detected in the presence of $100 \mu \mathrm{g} / \mathrm{ml}$ ferritin (data not shown).

The results of the present study provide evidence that the HA - generated by $\mathrm{fp} 2$ induces the strand breaks of DNA. Several lines of evidence ${ }^{30-32)}$ have indicated that the various quinone antibiotics such as adriamycin and bleomycin which are structurally similar to alloxan, are reduced to the semiquinone radicals by $\mathrm{fp} 2$, in vivo and in vitro. The semiquinone radicals react rapidly with oxygen to produce $\mathrm{O}_{2}^{-}, \mathrm{H}_{2} \mathrm{O}_{2}$ and $\mathrm{HO} \cdot{ }^{32,33)}$ In biological system, $\mathrm{HO} \cdot$ reacts with cellular DNA, thereby the strand breaks of DNA are induced. ${ }^{32,34)}$ These events of quinone antibiotics may ultimately cause the tumor cell death. We have demonstrated that the generation of $\mathrm{HA} \cdot$ in the islet cell is catalyzes by the $\mathrm{fp} 2 .{ }^{19)}$ In addition, alloxan accumulates rapidly and preferentially in islet. ${ }^{35)}$ Therefore, we inferred that the HA . generated by fp2 was involved in the process of the pancreatic $\beta$-cell death and the diabetes mellitus.

MacDonald et al. ${ }^{36)}$ have shown that $\beta$-cell of rat pancreatic islet contains a high amount of ferritin. Other 
workers ${ }^{37-39)}$ demonstrated that ferritin and fp2 were found in nuclear of the rat liver cell. These findings suggest a possibility that ferritin and fp2 play an important role in damaging DNA by alloxan in pancreatic islet cells. To explain the exact mechanism of the diabetogenic action of alloxan, more studies are required to clarify the existence of $\mathrm{fp} 2$ in pancreatic cell, especially in $\beta$-cell.

\section{REFERENCES}

1) I. Lundquist, C. Rerup, Eur. J. Pharmacol., 2, 35 (1967).

2) R. E. Heikkila, B. Winstor, G. Cohen, H. Barden, Biochem. Pharmacol., 25, 1085 (1976).

3) K. Grankvist, S. Marklund, I. B. Täljedal, Nature (London), 294, 158 (1981).

4) K. Grankvist, S. Marklund, J. Sehlin, I. B. Täljedal, Biochem. J., 182, 17 (1979).

5) L. J. Fischer, S. A. Hamburger, Diabetes, 29, 213 (1980).

6) K. Sakurai, T. Miura, T. Ogiso, Chem. Pharm. Bull., 38, 993 (1990).

7) Y. Uchigata, H. Yamamoto, A. Kawamura, H. Okamoto, J. Biol. Chem., 257, 6084 (1982).

8) N. Takasu, I. Komiya, Y. Nagasawa, T. Yamada, J. Biol. Chem., 266, 2112 (1991).

9) K. Grankvist, S. Marklund, Life Sci., 33, 2535 (1983).

10) A. El-Hage, E. H. Herman, G. C. Yang, Res. Commun. Chem. Pathol. Pharmacol., 52, 341 (1986).

11) L. A. Idahl, A. Lernmark, J. Sehlin, I. B. Täljedal, Biochem. J., 162, 9 (1977).

12) S. D. Aust, L. A. Morehouse, C. E. Thomas, J. Free Radic. Biol. Med., 1, 3 (1985).

13) P. Aisen, I. Listowsky, Annu. Rev. Biochem., 49, 357 (1980).

14) D. L. Jacobs, G. D. Watt, R. B. Frankel, G. C. Papaefthymiou, Biochemistry, 28, 1650 (1989).

15) C. E. Thomas, S. D. Aust, J. Biol. Chem., 261, 13064 (1986).
16) H. P. Monteiro, C. C. Winterbourn, Arch. Biochem. Biopys., 271, 536 (1989).

17) G. Carlin, R. Djursater, FEBS Lett., 177, 27 (1984).

18) P. Biemond, A. J. G. Swaak, C. M. Beindorff, J. F. Koster, Biochem. J., 239, 169 (1986).

19) K. Sakurai, T. Ogiso, Biol. Pharm. Bull., 17, 1451 (1994).

20) K. Sakurai, K. Haga, T. Ogiso, Chem. Pharm. Bull., 40, 2147 (1992).

21) L. Ernster, P. Siekeviz, G. E. Palade, J. Cell Biol., 15, 541 (1977).

22) Y. Yasukochi, B. S. S. Masters, J. Biol. Chem., 251, 5337 (1976).

23) D. W. Reif, V. M. Samokyszyn, D. M. Miller, S. D. Aust, Arch. Biochem. Biophys., 269, 407 (1989).

24) T. Miura, K. Sakurai, Life Sci., 43, 2145 (1988).

25) H. Okamoto, Biomed. Biochim. Acta, 44, 15 (1985).

26) K. Sakurai, K. Haga, T. Ogiso, Biol. Pharm. Bull., 17, 227 (1994).

27) B. H. Halliwell, FEBS Lett., 92, 321 (1978).

28) B. Halliwell, J. M. C. Gutteridge (eds.), "Free Radicals in Biology and Medicine," Clarendon Press, Oxford, 1985.

29) C. C. Winterbourn, Biochem. J., 207, 609 (1982).

30) V. Berlin, W. A. Haseltime, J. Biol. Chem., 256, 4747 (1981).

31) L. Giloni, M. Takeshita, F. Johnson, C. Iden, A. P. Grollman, J. Biol. Chem., 256, 8608 (1981).

32) B. K. Sinha, Chem.-Biol.Interact., 69, 293 (1989).

33) C. A. Pritsos, A. C. Sartonelli, Cancer Res., 46, 3528 (1986).

34) J. H. Doroshow, Proc. Natl. Acad. Sci. U.S.A., 83, 4514 (1986).

35) W. J. Malaisse, F. Malaisse-Lagae, A. Sener, D. G. Pipeleers, Proc. Natl. Acad. Sci. U.S.A., 79, 927 (1982).

36) M. J. MacDonald, J. D. Cook, M. L. Epstein, C. H. Flowers, FASEB J., 8, 777 (1994).

37) W. W. Franke, B. Deumling, B. Ermen, E.-D. Jarash, H. Kleiing, J. Cell Biol., 46, 379 (1970).

38) A. G. Smith, P. Carthew, J. E. Francis, R. E. Edwards, D. Dinsdale, Hepatology, 12, 1399 (1990).

39) L. M. Nutter, E. O. Ngo, G. R. Fisher, P. L. Gutierrez, J. Biol. Chem., 267, 2474 (1992). 